\section{Cadmium and the kidney}

An important toxicological feature of cadmium (Cd) is its long biological half life in man (10-30 years). In the newborn, Cd is virtually absent but by the age of 50 the body burden of cadmium may have increased up to $20-30 \mathrm{mg}$ and in those with occupational exposure it may reach values as high as $200-300 \mathrm{mg}$. Furthermore, $\mathrm{Cd}$ concentrates in vital organs, particularly in the kidneys, where it is bound mainly to metallothionein, a low molecular weight protein that offers some protection against $\mathrm{Cd}$ toxicity. Excessive exposure to $\mathrm{Cd}$ has been linked to the occurrence of pulmonary insufficiency, renal disturbances, and osteomalacia. All these effects have been described in $\mathrm{Cd}$ workers whereas only the kidney and bone lesions (Itai-Itai disease) have been reported in elderly Japanese women exposed to $\mathrm{Cd}$ by the oral route. ${ }^{1}$ The question of the carcinogenicity of $\mathrm{Cd}$ in man is still unsettled. ${ }^{2}$

In long term occupational or environmental exposure to $\mathrm{Cd}$ the kidney is considered the critical organ - that is, the first to be damaged. Since the first description of the nephrotoxic effects of $\mathrm{Cd}$ by Friberg, ${ }^{3}$ several features of cadmium induced nephropathy have been clarified. The earliest sign is an increased proteinuria that is frequently similar to the proteinuria described by Butler and Flynn ${ }^{4}$ in tubular disorders. The measurement of specific low molecular weight proteins in the urine is now routinely performed to assess the integrity of proximal tubular function in workers exposed to $\mathrm{Cd}$. The analytical difficulties resulting from the instability of $\beta_{2}$-microglobulin in acid urine may be obviated by measuring urinary retinol binding protein concentrations. ${ }^{56}$

Since inhalation is the major route of exposure to $\mathrm{Cd}$ in industry, attempts have been made to assess the relation between the prevalence of renal effects and integrated exposure to airborne $\mathrm{Cd}$. Our proposal that exposure to $20 \mu \mathrm{g} \mathrm{Cd} / \mathrm{m}^{3}$ (respirable dust from soluble salts) for $\mathbf{4 0}$ hours a week for 20 years is the threshold effect concentration for increased urinary excretion of specific proteins ${ }^{78}$ has been corroborated by several studies. $^{9-12}$

With the development of neutron activation techniques allowing the "in vivo" determination of $\mathrm{Cd}$ in tissues, it has been possible to assess directly the critical concentration of $\mathrm{Cd}$ in the renal cortex. ${ }^{13-15}$ When the concentration of $\mathrm{Cd}$ in the renal cortex reaches $215 \mathrm{ppm}$, renal dysfunction is likely to develop in $10 \%$ of male workers occupationally exposed to the metal. The occurrence of kidney damage leads to a progressive decrease of $\mathrm{Cd}$ concentration in the cortex. The relations between the concentration of $\mathrm{Cd}$ in the urine and the renal cortex and the prevalence of increased proteinuria have also allowed a biological threshold for urinary $\mathrm{Cd}$ to be proposed. In Cd workers a concentration below $10 \mu \mathrm{g}$ $\mathrm{Cd} / \mathrm{g}$ creatinine is rarely associated with increased proteinuria. ${ }^{1617}$

So far, the concept of the critical concentration of Cd refers to the total amount of metal stored in the kidney cortex. Nevertheless, only a small fraction is not bound to metallothionein and capable of reacting with the critical sites to induce nephrotoxicity. Animal data indicate that the renal concentration of nonmetallothionein bound $\mathrm{Cd}$ needed to cause an increased $\beta_{2}$-microglobulinuria is approximately $2 \mathrm{ppm}$ (unpublished observations). This value corresponds to $1 \%$ of the critical concentration of total $\mathrm{Cd}$ in the kidney of adult male workers. There is now increasing evidence that the critical concentration of non-metallothionein bound $\mathrm{Cd}$ may be reached at even lower concentrations of total $\mathrm{Cd}$ in the kidney depending on the exposure conditions and exogenous or endogenous factors influencing renal cellular function - for example, the ability to synthetise metallothionein). For instance, the chronic administration of paracetamol in doses resulting in a reversible proximal tubular dysfunction renders rats more sensitive to the tubulotoxic action of $\mathrm{Cd}$. Another factor is aging which may substantially decrease the critical concentration of $\mathrm{Cd}$ associated with the development of tubular injury in animals. ${ }^{1819}$ Preliminary observations among the elderly living in $\mathrm{Cd}$ polluted areas indicate that the same phenomenon may occur in people. ${ }^{20-22}$

Several aspects of $\mathrm{Cd}$ nephropathy are still obscure or remain a matter of controversy. Epidemiological studies carried out among $\mathrm{Cd}$ workers have shown that an increased urinary excretion of high molecular weight proteins (albumin, for example) may be detected either as an isolated finding or in association with an increased excretion of low molecular weight proteins. ${ }^{716}$ Since an increased albuminuria without a concomitant change in the excretion of low molecular weight proteins probably results from an increased 
glomerular permeability, ${ }^{23}$ these results suggest that even at an early stage of intoxication, $\mathrm{Cd}$, at least in some individuals, interferes with glomerular function. Electronmicroscope and functional studies in animals tend to support this conclusion. ${ }^{1824}$ The molecular mechanisms by which $\mathrm{Cd}$ interferes with the tubular reabsorption of low molecular weight proteins and with the glomerular filtration of high molecular weight proteins probably differ. The former effect is presumably due to the non-metallothionein bound Cd released intracellularly during the breakdown of the reabsorbed hepatic Cd-thionein or during the normal turnover of the renal Cd-thionein. The mechanism by which $\mathrm{Cd}$ can alter glomerular function is unknown. There is some suggestion that $\mathrm{Cd}$ may exacerbate the processes involved in the aging of the kidneys. ${ }^{1819}$ Circulating antiglomerular basement membrane antibodies have also been found in animals treated with $\mathrm{Cd}$ but their pathological importance is unknown since they were not associated with deposits along the glomerular basement membrane. ${ }^{25}$ Measuring the reserve glomerular filtration capacity as recently suggested by RodriguesIturbe $e a^{26}$ may be a useful approach by which to solve the controversial issue of the early interference of $\mathrm{Cd}$ with glomerular function.

The long term health importance of an increased urinary excretion of low molecular weight proteins is also the subject of much debate. The Cd induced proteinuria seems to progress slowly but once started it is usually irreversible. ${ }^{1127}$ Because of the lack of progression to renal insufficiency, some authors consider that an isolated increased $\beta_{2}$-microglobulinuria has no health significance. Since a significant excess of deaths from renal diseases has been reported among workers with more than 15 years exposure to $\mathrm{Cd},{ }^{28}$ however, it has also been proposed that interference by $\mathrm{Cd}$ with the renal handling of proteins should be considered an adverse effect. Follow up studies are needed to assess the predictive value of increased urinary excretion of specific proteins in workers exposed to $\mathrm{Cd}$.

The study of the impact on health of environmental pollution by $\mathrm{Cd}$ in certain areas in Europe has provided discordant results. Several studies carried out in Belgium have shown that people who had lived in an industrial area (Liège) polluted by $\mathrm{Cd}$ had accumulated more $\mathrm{Cd}$ in their renal cortex and liver than residents from other areas of Belgium and that this could be linked with an exacerbation of the age related decline in renal function. ${ }^{2122}$ Studies carried out in an industrial area of Germany (Stolberg) ${ }^{29}$ and in a rural area in the United Kingdom (Shipham) ${ }^{\mathbf{3 0}}$ where the soil is contaminated by $\mathrm{Cd}$ did not show renal effects that could be attributed to the environmental pollution by $\mathrm{Cd}$. These discrepancies, how- ever, may be more apparent than real since comparison of the average concentrations of $\mathrm{Cd}$ in urine (which reflects the accumulation of $\mathrm{Cd}$ in the target organ) indicates that the uptake of $\mathrm{Cd}$ by the Liège residents was higher than in the United Kingdom and in Germany.

An increased incidence of urinary tract stones in workers exposed to $\mathrm{Cd}$ has been reported in the United Kingdom ${ }^{41-34}$ and in Sweden. ${ }^{35}$ Further investigations are needed to establish the importance of this phenomenon, since there are no reports of kidney stones from other countries. In particular, it is not yet known whether hypercalciuria ${ }^{36}$ can precede the occurrence of increased specific proteinuria and whether the prevention of the latter is sufficient to prevent the induction of renal stones by $\mathrm{Cd}$.

Industrial Toxicology Unit,

R R LAUWERYS and A M BERNARD

Department of Occupational Medicine and Hygiene,

Catholic University of Louvain,

30.54 Clos Chapelle-aux-Champs,

1200 Brussels, Belgium.

\section{References}

${ }^{1}$ Tsuchiya K. Cadmium studies in Japan. A review. Amsterdam: Elsevier/North-Holland Biomedical Press, 1978.

2 Bernard A, Lauwerys R. Effects of Cd exposure in humans. In: Foulkes EC, ed. Cadmium. Handbook of experimental pharmacology. Vol 80. Berlin: Springer Verlag, 1986:135-77.

${ }^{3}$ Friberg L. Health hazards in the manufacture of alkaline accumulators with special reference to chronic $\mathrm{Cd}$ poisoning. Acta Med Scand 1950;138 (suppl 240):1-124.

${ }^{4}$ Butler EA, Flynn FV. The proteinuria of renal tubular disorders. Lancet 1958;ii:978-80.

${ }^{5}$ Bernard AM, Moreau D, Lauwerys RR. Comparison of retinolbinding protein and $\beta_{2}$-microglobulin determination in urine for the early detection of tubular proteinuria. Clin Chim Acta 1982;126:1-7.

${ }^{6}$ Beetham R, Dawnay A, London J, Cattwell WR. A radioimmunoassay for retinol-binding protein in serum and urine. Clin Chem 1985;31:1364-7.

${ }^{7}$ Lauwerys R, Buchet JP, Roels H, Brouwers J, Stanescu D. Epidemiological survey of workers exposed to Cd. Arch Environ Health 1974;28:145-8.

${ }^{8}$ Lauwerys R, Stanescu D, Roels H, Buchet JP. Effects of cadmium on the lungs. Cadmium 77. Proceedings of the lst international cadmium conference. San Francisco, 1977. London: Metal Bulletin Limited, 1978:201-4.

${ }^{9} \mathrm{Kjellström} \mathrm{T.} \mathrm{Accumulation} \mathrm{and} \mathrm{renal} \mathrm{effects} \mathrm{from} \mathrm{Cd}$. $\mathrm{A}$ doseresponse study. Stockholm: Department of Environmental Hygiene, Karolinska Institute, 1977. (Thesis.)

${ }^{10}$ Falck FJ Jr, Fine LJ, Smith RG, et al. Occupational Cd exposure and renal status. Am J Ind Med 1983;4:541-9.

${ }^{11}$ Elinder C-G, Edling C, Lindberg E, Kågedal B, Vesterberg $O$. $\beta_{2}$-Microglobulinuria among workers previously exposed to $\mathrm{Cd}$ : follow-up and dose-response analysis. $\mathrm{Am} J$ Ind $\mathrm{Med}$ 1985;8:553-64.

12 Ellis KJ, Cohn SH, Smith TJ. Cadmium inhalation exposure estimates: their significance with respect to kidney and liver cadmium burden. J Toxicol Environ Health 1985;15:173-87. 
${ }^{13}$ Roels H, Lauwerys R, Buchet JP, et al. In vivo measurement of liver and kidney $\mathrm{Cd}$ in workers exposed to this metal. Environ Research 1981;26:217-40.

${ }^{14}$ Roels H, Lauwerys R, Dardenne AN. The critical level of Cd in human renal cortex: a reevaluation. Toxicol Lett 1983;15: 357-60.

${ }^{15}$ Ellis KJ, Morgan WC, Zanzi I, Yasumura S, Vartsky D, Cohn SH. Critical concentration of Cd in human renal cortex: dose-effect studies in Cd smelter workers. J Toxicol Environ Health 1981;7:691-703.

${ }^{16}$ Bernard A, Buchet JP, Roels H, Masson P, Lauwerys R. Renal excretion of proteins and enzymes in workers exposed to $\mathrm{Cd}$ Eur J Clin Invest 1979;9:11-22.

${ }^{17}$ Buchet JP, Roels H, Bernard A, Lauwerys R. Assessment of renal function of workers exposed to inorganic lead, Cd or mercury vapour. J Occup Med 1980;22:741-9.

${ }^{18}$ Bernard A, Ouled A, Viau C, Oldiges H, Lauwerys R. Dose/effect relationships for the nephrotoxic action of $\mathrm{Cd}$ in rats. Influence of age and exposure mode. Proceedings of the 5th international conference on metals in the environment, Athens, 1985. Edinburgh: CEP Ltd, 1985:70-2.

${ }^{19}$ Nomiyama K, Nomiyama H, Yotoriyama M. Ageing, a factor aggravating chronic toxicity of Cd. Toxicol Lett 1980;6:225-30.

${ }^{20}$ Lauwerys R, Roels H, Bernard A, Buchet JP. Renal response to $\mathrm{Cd}$ in a population living in a non-ferrous smelter area in Belgium. Int Arch Occup Environ Health 1980;45:271-4.

${ }^{21}$ Roels H, Lauwerys R, Buchet JP, Bernard A. Environmental exposure to $\mathrm{Cd}$ and renal function of aged women in three areas of Belgium. Environ Res 1981;24:117-30.

${ }^{22}$ Lauwerys R, Hardy R, Job M, et al. Environmental pollution by $\mathrm{Cd}$ and $\mathrm{Cd}$ body burden: an autopsy study. Toxicol Lett 1984;23:287-9.

${ }^{23}$ Bernard A, Viau C, Ouled A, Lauwerys R. Competition between low and high molecular weight proteins for renal tubular uptake. Nephron (in press).

${ }^{24}$ Aughey E, Fell GS, Scott R, Black M. Histopathology of early effects of oral $\mathrm{Cd}$ in the rat kidney. Environ Health Perspect 1984;54:153-61.

${ }^{25}$ Bernard A, Lauwerys R, Gengoux P, et al. Anti-laminin and antitype IV procollagen antibodies in Sprague-Dawley and brown
Norway rats chronically exposed to Cd. Toxicology 1984;31:307-13.

${ }^{26}$ Rodriguez-Iturbe B, Herrera J, Garcia R. Response to acute protein load in kidney donors and in apparently normal postacute glomerulonephritis patients: evidence for glomerular hyperfiltration. Lancet 1985;ii:461-4.

${ }^{27}$ Roels H, Djubgang J, Buchet JP, Bernard A, Lauwerys R. Evolution of cadmium-induced renal dysfunction in workers removed from exposure. Scand $J$ Work Environ Health 1982;8:191-200.

${ }^{28}$ Kjellström T, Friberg L, Rahnster D. Mortality and cancer morbidity among cadmium-exposed workers. Environ Health Perspect 1979;28:199-204.

${ }^{29}$ Ewers U, Brockhaus A, Dolgner R, et al. Environmental exposure to $\mathrm{Cd}$ and renal function of elderly women living in two cadmium-polluted areas of West-Germany. Int Arch Occup Environ Health 1985;55:217-39.

${ }^{30}$ Barltrop D, Strehlow CD, Wells J. Health implications of Cd exposure in Shipham. Cadmium 83. Proceedings of the 4th international cadmium conference, Munich, 1983. London and New York: Cadmium Association and International Lead Zinc Research Association, 1984: 101-3.

${ }^{31}$ Adams RC, Harrison JG, Scott P. The development of cadmiuminduced proteinuria, impaired renal function and osteomalacia in alkaline battery workers. $Q \mathrm{~J} \mathrm{Med} 1969 ; 38: 425-33$.

${ }^{32}$ Kazantzis G. Some long-term effects of Cd on the human kidney. Proceedings of the lst international cadmium conference. San Francisco, 1977. London: Metal Bulletin Ltd, 1977: 194-8.

${ }^{33}$ Scott R, Mills EA, Fell GS, et al. Clinical and biochemical abnormalities in coppersmith exposed to cadmium. Lancet 1976;ii:396-9.

${ }^{34}$ Scott R, Patterson PJ, Burns R, et al. Hypercalciuria related to Cd exposure. Urology 1978;11:462-5.

${ }^{35}$ Axelsson B. Urinary calculus in long term exposure to Cd. Proceedings of the XIV international congress on occupational health. 1963:939-42.

${ }^{36}$ Scott R, Haywood JK, Boddy K, Williams ED, Harvey M, Patterson PJ. Whole body calcium deficit in cd-exposed workers with hypercalciuria. Urology 1980;15:356-9. 